\title{
Projekt Kruh prstenu aneb antropologie sexuality: Vladimír Drápal
}

\author{
Jaroslav Malina \\ Ústav antropologie Př́rodovědecké fakulty Masarykovy univerzity, Vinařská 5, 60300 Brno
}

Projekt Kruh prstenu: Světové dějiny sexuality, erotiky a lásky od počátkủ do současnosti v reálném životě, krásné literatuře, výtvarném umění a dílech českých malíru a sochařu inspirovaných obsahem této knihy vznikl počátkem devadesátých let minulého století. Představuje vytvoření reprezentativní trojsvazkové publikace a sbírky erotik českých malírů a sochařů.

V jednotlivých číslech časopisu Anthropologia integra jsou uveřejňovány medailony zúčastněných výtvarníků a reprodukovány některé z jejich artefaktů vytvořených pro projekt Kruh prstenu (Malina 2010).

Dnes: malíŕ, grafik a sochař Vladimír Drápal.

\section{THE PROJECT THE CIRCLE OF THE RING OR ANTHROPOLOGY OF SEXUALITY: VLADIMÍR DRÁPAL}

The Project The Circle of the Ring: The World History of Sexuality, Eroticism and Love from the Beginnings up to the Present Day in Real Life, Belle-Lettres, Visual Art and in the Works of Czech Painters and Sculptors Inspired by the Content of this Book arose at the beginning of the 1990s. It presents the formation of the representative publication in three volumes and a collection of erotica of Czech painters and sculptors. Particular volumes of the journal Anthropologia integra will include short profiles on the participating artists as well as reproductions of some of their artefacts created for the project The Circle of the Ring (Malina 2010).

Today: painter, graphic artist and sculptor Vladimír Drápal.

\section{PROJEKT DER KREIS DES FINGERRINGES ODER ANTHROPOLOGIE DER SEXUALITÄT: VLADIMÍR DRÁPAL}

Mit dem Projekt Der Kreis des Fingerringes: Weltgeschichte der Sexualität, Erotik und Liebe von den Anfängen bis zur Gegenwart - dargestellt im realen Leben, in der Belletristik, der Bildenden Kunst und in Kunstwerken vom Inhalt des vorliegendes Buches inspirierter tschechischer Maler und Bildhauer, das Anfang der neunziger Jahre des vorigen Jahrhunderts entstand, wurde eine repräsentative dreibändige Publikation samt einer Sammlung von Erotika tschechischer Maler und Bildhauer gestaltet.

In den einzelnen Heften der Zeitschrift Anthropologia integra werden die Porträts der am genannten Projekt beteiligten Künstler veröffentlicht und einige für Den Kreis des Fingerringes geschaffene Artefakte wiedergegeben (Malina 2010).

Heute: Maler, Grafiker und Bildhauer Vladimír Drápal.

\section{VLADIMÍR DRÁPAL}

Malír, grafik a sochař Vladimír Drápal pochází z Tvarožné, moravské obce rozložené na jižním úpatí Drahanské vrchoviny. Zde se narodil 28. ř́ijna 1921. Měl se stát sedlákem a pekařem jako jeho otec, a tak již od dětství pracoval v hospodářství a vyučil se i řemeslu. O své životní dráze však rozhodl jinak a zahájil ji absolvováním brněnské Školy uměleckých řemesel v letech 1938-1942 ve speciálce dekorativní malby u profesora Emanuela Hrbka. Jeho dalšímu studiu ovšem zabránila válka a německá okupace země, během níž byl v různých provozech nuceně nasazen jako pomocný dělník a od konce roku 1944 jako kopáč zákopů v rakouském Menhofu. Po osvobození Československa vystudoval v letech 1945-1949 pražskou Vysokou školu uměleckoprůmyslovou ve speciálce užité malby vedené profesorem Josefem Kaplickým. Po studiu se natrvalo vrací do svého domova, pomáhá otci v hospodářství, s elánem se zapojuje do spolkové a výstavní činnosti brněnských výtvarníků a v roce 1961 zahajuje i své pedagogické působení na Filozofické a Pedagogické fakultě Masarykovy univerzity (tehdy přejmenované na Univerzitu Jana Evangelisty Purkyně) v Brně. 


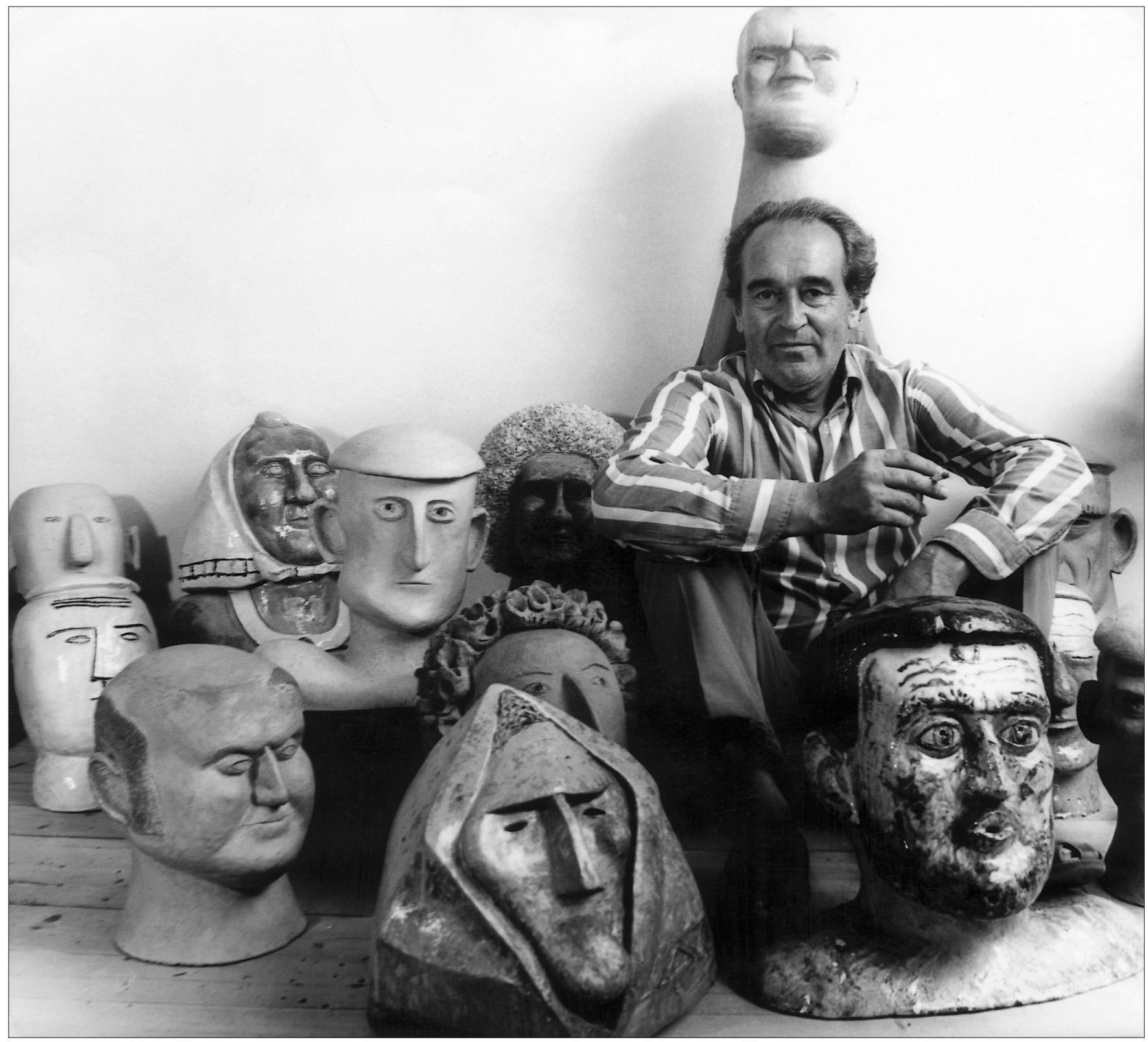

Obr. 1. Vladimír Drápal (polovina sedmdesátých let 20. století). Foto Josef Tichý.

Vladimír Drápal (mid 1970s).

Vladimír Drápal (Mitte der siebziger Jahre des 20. Jahrhunderts).

Klíčem k Drápalově tvorbě je umělcova bytostná zakořeněnost $\mathrm{v}$ rodném prostředí. Toto harmonické fluidum, jehož prizmatem $\mathrm{k}$ němu vstupuje svět, ho od dětství formovalo a otvíralo mu cestu k prŕrodě, která jej navždy uhranula svou životadárnou silou a svým řádem. Pronikat do něj, oddělovat zrno od plev se dlouhá léta učil za pluhem. Odtud vše, co vychází z jeho rukou, je téhož skupenství jako půda, kolébka, chléb, matka všeho živého. Umělcovou doménou je skutečnost. Přistupuje k ní, aby smysly, citem a rozumem pronikl pod její povrch a cestou na sebe vrstvených zážitků dospěl $\mathrm{k}$ ucelené představě o podstatném, jež pak vyslovuje s jistotou kovové ražby.

Východiskem a nosným článkem Drápalovy bohatě rozvětvené tvorby se stala kresba. Je soustředěna do vitální obrysové linie, která se silným napětím a pregnancí klene a svírá dynamicky rozpínavý tvar a v jejímž strohém duktu jako by dozníval monumentální rytmus př́rodního panorámatu. Je charakteristické, že přes postupný abstrakční proces, jímž Drápalova kresba a veškerý výtvarný projev v logicky plynulém vývoji prochází a který funkční nadsázkou a tvarovou deformací směřuje k lineárnímu znaku, nedochází nikdy k oslabení sdělnosti, robustní smyslovosti a výrazové síly tohoto projevu. A především to svědčí o expresionistickém původu Drápalova výtvarného projevu.

Ohniskem celoživotního výtvarného zájmu Vladimíra Drápala je člověk a jeho odvěký druh - zvíre. Do životního prostoru zviŕat vstupuje a smyslu jejich bytí se dotýká sondami invenčně bohatých kreslených cyklů, promítaných do suché 


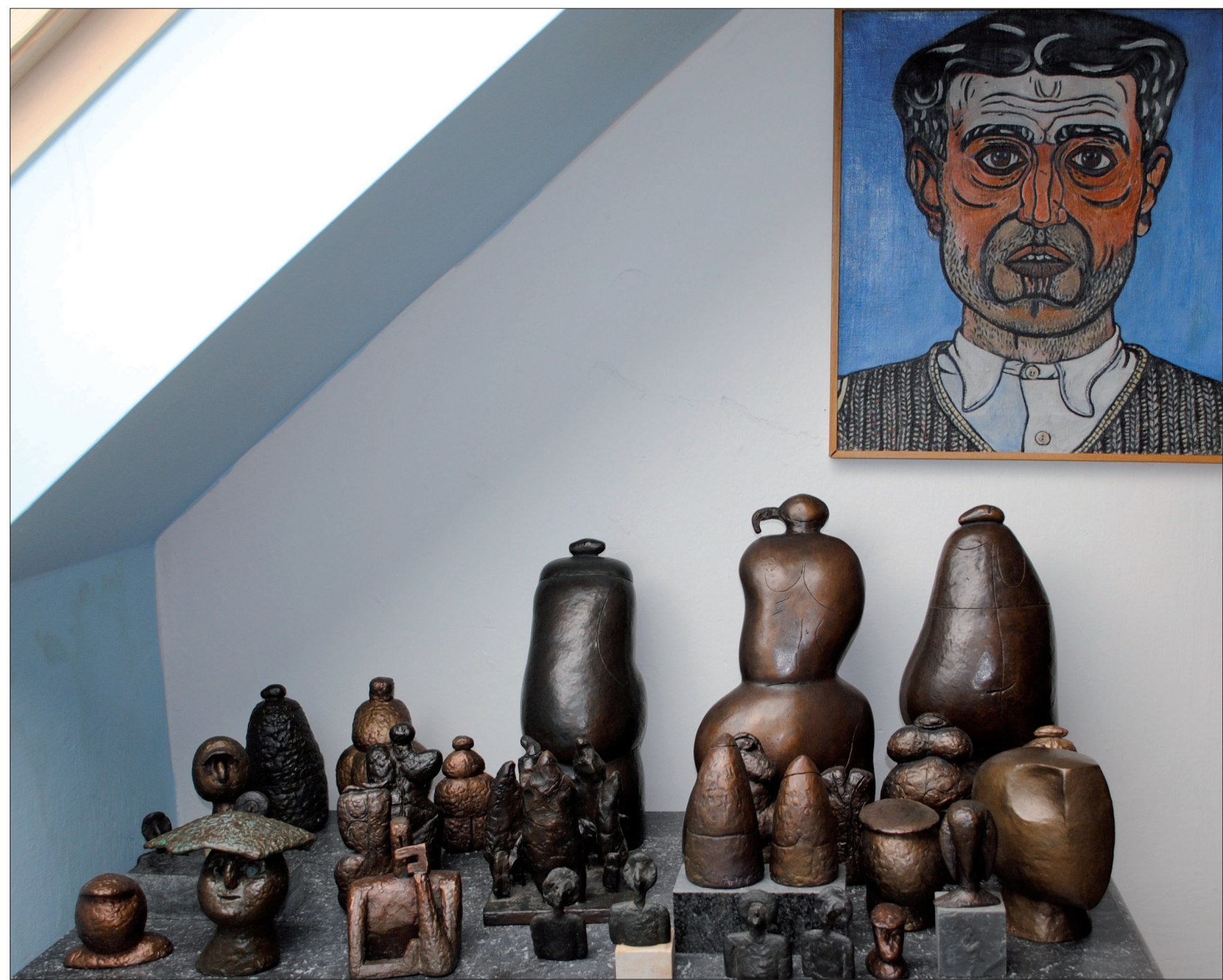

Obr. 2. Autoportrét (1944), olej, plátno 49,5x45,5 cm; bronzové plastiky. Foto: Stáňa Bártová.

Self-portrait (1944), oil, canvas, $49.5 \times 45.5 \mathrm{~cm}$; bronze sculptures.

Selbstbildnis (1944), Öl auf Leinwand, 49,5x45,5 cm; Bronzeskulptur.

jehly a leptu. Vznikají tak jeho Tvaroženské kopačky (1960), Selská hlava (1964-1965), Kuñ (1966-1968), Venuše (1967), Dvojice (1968-1969), Zvíre (1969-1973) a Družstevnice na kolech (1975-1976). Od sklonku šedesátých let se pak jimi inspiruje ve své plastice, postupně realizované v keramice, ve dřevě i v kovu. Umělcova rostoucí potřeba uchopit realitu v celé její nezastupitelné hmotnosti a variabilitě tak dochází svého naplnění.

Zvláštní a pro moderní české sochařství podnětnou kapitolou se v Drápalově plastice stávají keramické a dřevěné Hlavy tvaroženských sousedů a sousedek, do jejichž svérázné mentality umělec proniká jadrnou tvarovou a barevnou zkratkou. Životním tématem, $\mathrm{k}$ němuž se ve své skulptuře neustále vrací, je kůň, jeho velká láska a přítel čistého srdce. Láká jej však i živočišná smyslnost zvířecího organismu, jeho teplo, měkkost a pružnost. $\mathrm{V}$ námětu dvojic ho zajímá jednota věčných protikladů základních článků lidského rodu. A vrací se i k věčně znepokojivé venuši, dárkyni a udržovatelce života, jako by přejímal tajemné poselství z rukou pravěkého umělce zasaženého tajemstvím jejího poslání a hnětoucího první podobu ženy. Významnou součástí Drápalovy tvorby se stává nízký reliéf, který svého uměleckého dovršení dosahuje v osmdesátých letech, zejména bronzovými variacemi Dvojic. Jejich tence vrstvené kompozice citlivě modulovaného povrchu a světelně rafinovaného obrysu se svou sublimovanou smyslovostí, harmonií a noblesou vzdáleně přibližují duchu mistrovského reliéfu starověkého Egypta.

Sochařskou tvorbu Vladimíra Drápala charakterizuje robustní, mocně klenutý a rozpínavý objem mohutného vnitřního napětí, akcentovaný funkčními vrypy grafického původu. Naléhavostí a upřímností sdělení a drsnou bezprostředností svého výrazu pak jeho plastika připomíná tvorbu raných fází umění minulosti.

Logickým vyústěním Drápalovy tvorby se již od sklonku šedesátých let stávají jeho sochařské realizace, které výrazně dotvářejí charakter zejména brněnských a moravských exte- 


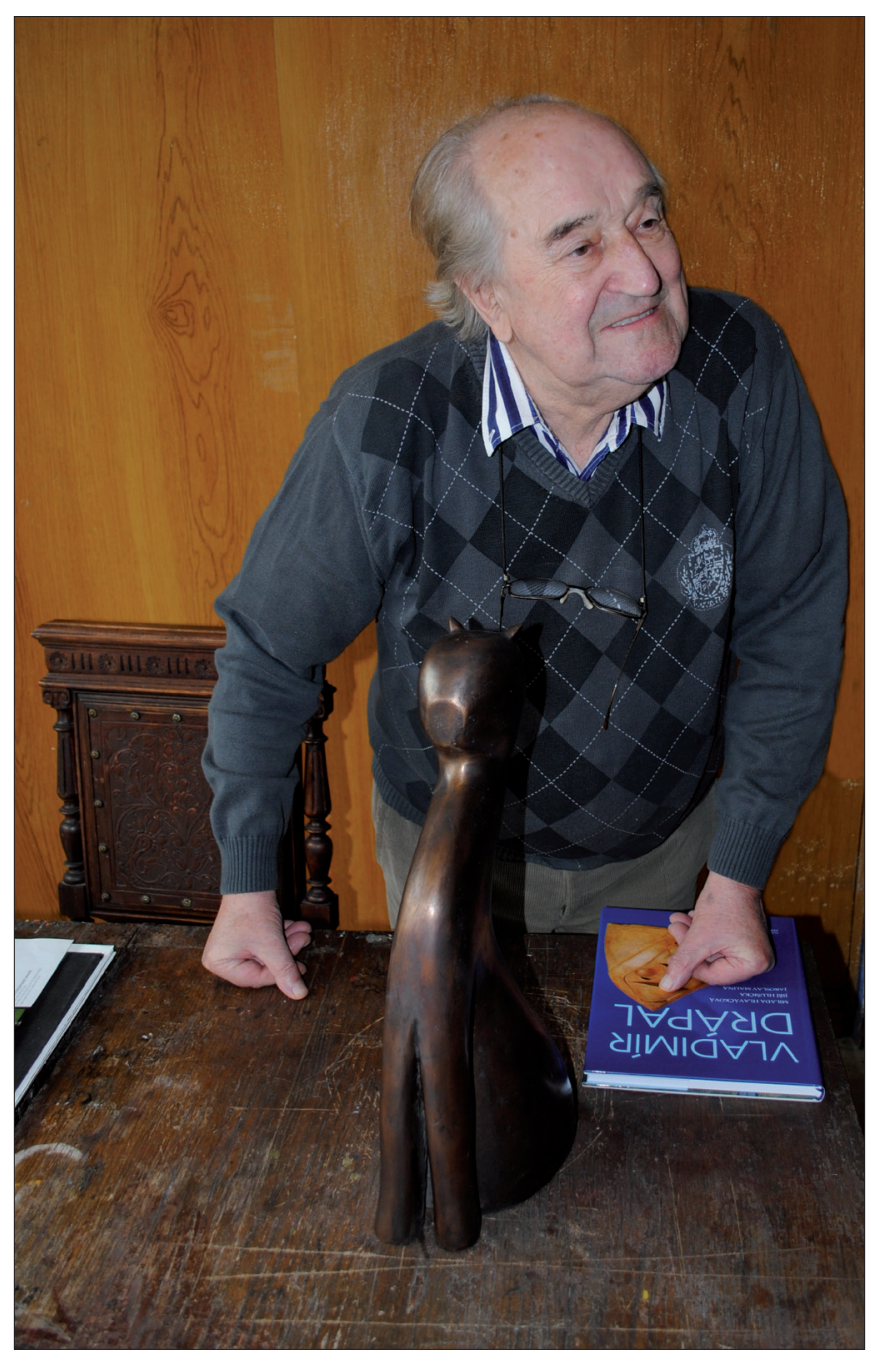

Obr. 3. Vladimír Drápal (2010). Foto: Stáňa Bártová.

Vladimír Drápal (2010)

Vladimír Drápal (2010)

riérů a interiérů. Jejich myšlenková průraznost, rozpínající tvar v naléhavost výzvy, jakož i smysl pro řád a velkou formu svědčí o přirozených předpokladech umělce pro monumentální tvorbu.

Průběžně doplňuje Vladimír Drápal svou sochařskou tvorbu drobnou keramikou a voskovou i skleněnou plastikou. K malířství, námětově čerpanému z rodného prostředí, jímž ve čtyřicátých letech začínal svou výtvarnou dráhu, se umělec vrací $\mathrm{v}$ několika časových vlnách, vždy znovu lákán expresivitou barvy. Z posledního období pocházejí jeho temperové hlavy a obrázky na skle a zejména jeho nesčetné kresby stromů.

Dílo Vladimíra Drápala je ve svých kořenech kompaktní a svébytné. Léta trpělivě zraje vlastním poznáním. Je optimistické, pravdivé a lidské. Jeho umění tvoří pozoruhodnou kapitolu českého výtvarného umění druhé poloviny dvacátého století.

Život a dílo Vladimíra Drápala jsou podrobně popsány v monografii: Hlaváčková, Milada - Hlušička, Jiří - Malina, Jaroslav, Vladimír Drápal. Brno: Akademické nakladatelství CERM, 2010.

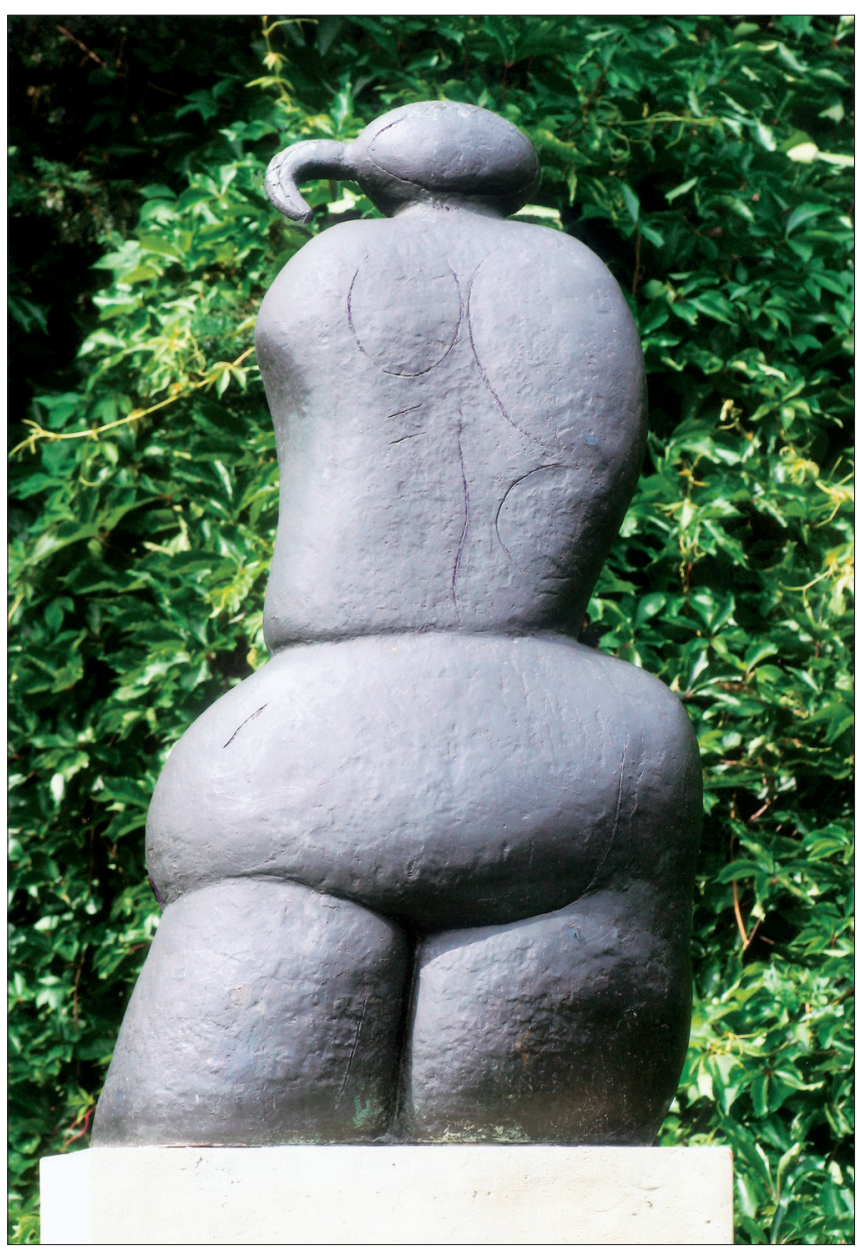

Obr. 4. Venuše (1982), bronz, výška 132 cm, v parku pavilonu Anthropos Moravského zemského muzea v Brně. Foto: Jiří Hlušička.

Venus (1982), bronze, height $132 \mathrm{~cm}$, at the park of Anthropos Pavilion of the Moravian Regional Museum in Brno.

Venus (1982), Bronze, Höhe $132 \mathrm{~cm}$, im Pisárky-Park bei Anthropos, einer Ausstellungshalle des Mährischen Landesmuseums in Brno.

\section{VLADIMÍR DRÁPAL}

Painter, graphic artist and sculptor Vladimír Drápal comes from Tvarožná, a Moravian village located in the southern foothills of the Drahanska Vrchovina Highlands, where he was born on 28 October 1921. He was supposed to become a farmer and baker, like his father, so he worked on the farming estate and learned the trade from childhood. He decided on a different career path that began with studies at the School of Applied Arts in Brno from 1938-1942, where he specialized in decorative painting with Professor Emanuel Hrbek. Further studies were impeded by the Second World War and the German occupation of the Czech lands. During this time, he was obliged to work as a labourer in various factories and from the end of 1944 as a ditch-digger in Menhof, Austria. After the liberation of Czechoslovakia, he studied from 1945-1949 at the Institute of Applied Arts in Prague, graduating with the specialization of applied painting under the guidance of Professor Josef Kaplický. After graduating, he returned home permanently to help his father with the farm and to become 


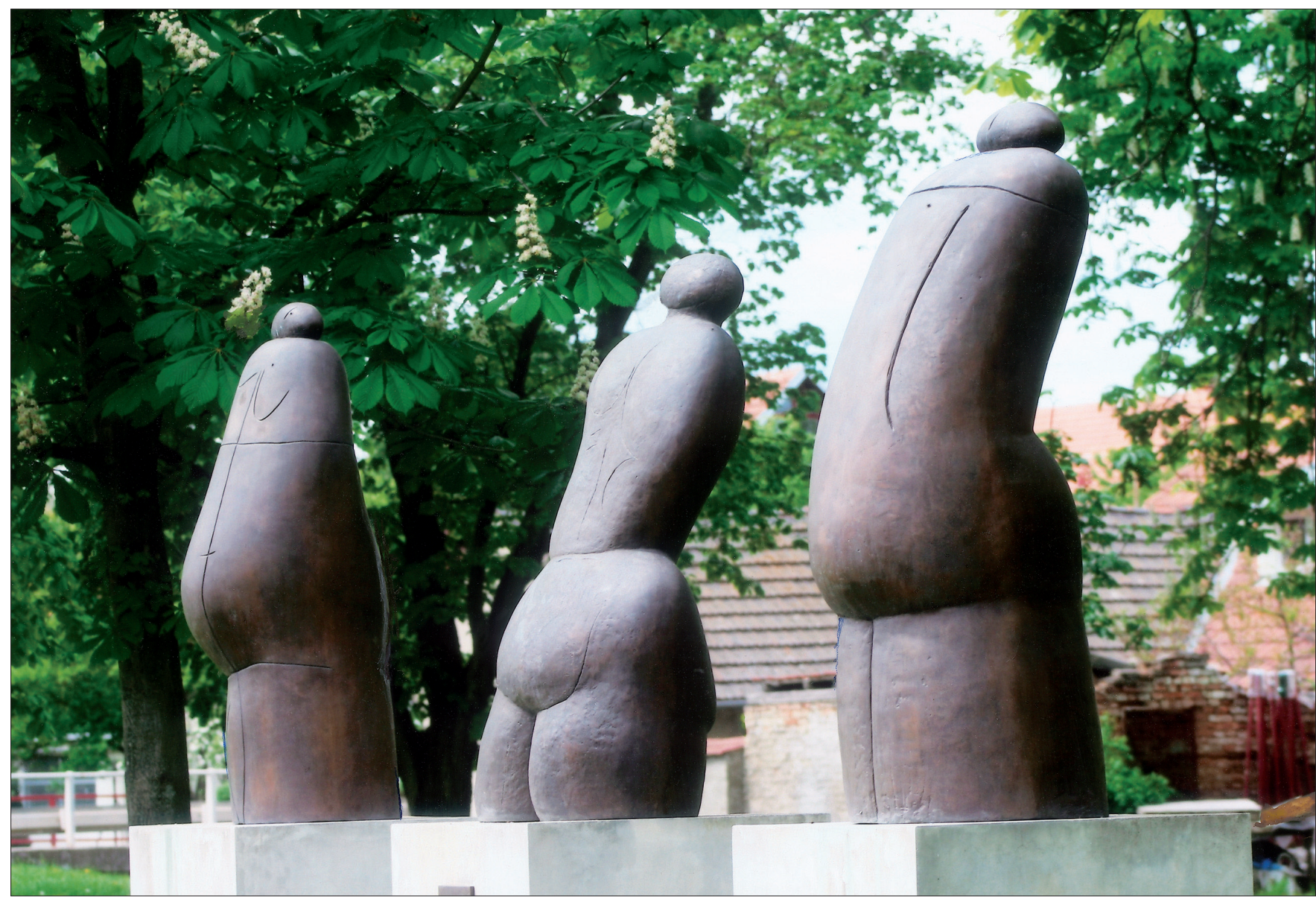

Obr. 5. Venuše (1982), trojice bronzových plastik v parku na návsi v Tvarožné, instalováno roku 2003. Foto: Jiří Hlušička.

Venus (1982), a grouping of three bronze sculptures in the park of the village square in Tvarožná, installed in 2003.

Drei Venusgestalten (1982), dreiteilige Bronzeskulptur im Dorfpark in Tvarožná, installiert 2003.

enthusiastically involved in the club and exhibition activities of Brno artists. In 1961 he began teaching at the Faculty of Arts and Education of Masaryk University (at that time renamed the University of Jan Evangelista Purkyně) in Brno.

The key to Drápal's oeuvre is his artistic and essential rootedness in his native environment. This harmonious fluidity, serving as a prism that allowed him to experience the world, was formative for him from childhood and opened his way to nature, forever enchanting him with its life-affirming power and order. He had already been learning how to penetrate nature, separating the grain from the chaff over the many years at the plough. From that point on, everything that he created could be grouped into land, cradle, bread or mound, the mother of all living things. His domain was reality. He approached it so that through his senses, emotions and reason he could permeate beyond its surface. Through the inter-layering of experiences, he matured to a comprehensive understanding of what was most important, later expressed through the certainty of metal embossing.

The starting point and cornerstone of Drápal's diverse oeuvre became drawing. It is concentrated into the vital contour line, which with its tension and cogency forms a dynamically expanding shape; in its terse ducts it is as if the monumental rhythm of a natural panorama was dissipating. It is characteristic that through the gradual process of abstraction, which Drápal's drawing and other creative expression undergo in a logically gradual process and which through functional exaggeration and formal distortion tend toward a linear sign, there is never a weakening of expression, robust sensuality or expressive power. This is primarily indicative of the expressionist origins of Drápal's creative expression.

The focus of creative interest of Vladimír Drápal's life's work is the human and his age-long partner - the animal. He enters their environment and probes the purpose of their being through his imaginative series of drawings expressed in dry point and etching. Thus emerge his works Tvaroženské kopačky (Women Field Diggers of the Village of Tvarožná, 1960), Selská hlava (Farmer's Head, 1964-1965), Kůñ (Horse, 19661968), Venuše (Venus, 1967), Dvojice (Pairs, 1968-1969), Zvíř (Animal, 1969-1973) and Družstevnice na kolech (Women Farm Co-op Workers on Bikes, 1975-1976). From the late sixties, he draws inspiration from them in his sculptures, eventually working with ceramics, wood and metal. The artist's growing need to grasp reality in all its irreplaceable mass and variability thus attains fulfillment.

Of Drápal's sculptural work, the unusual ceramic and wooden 


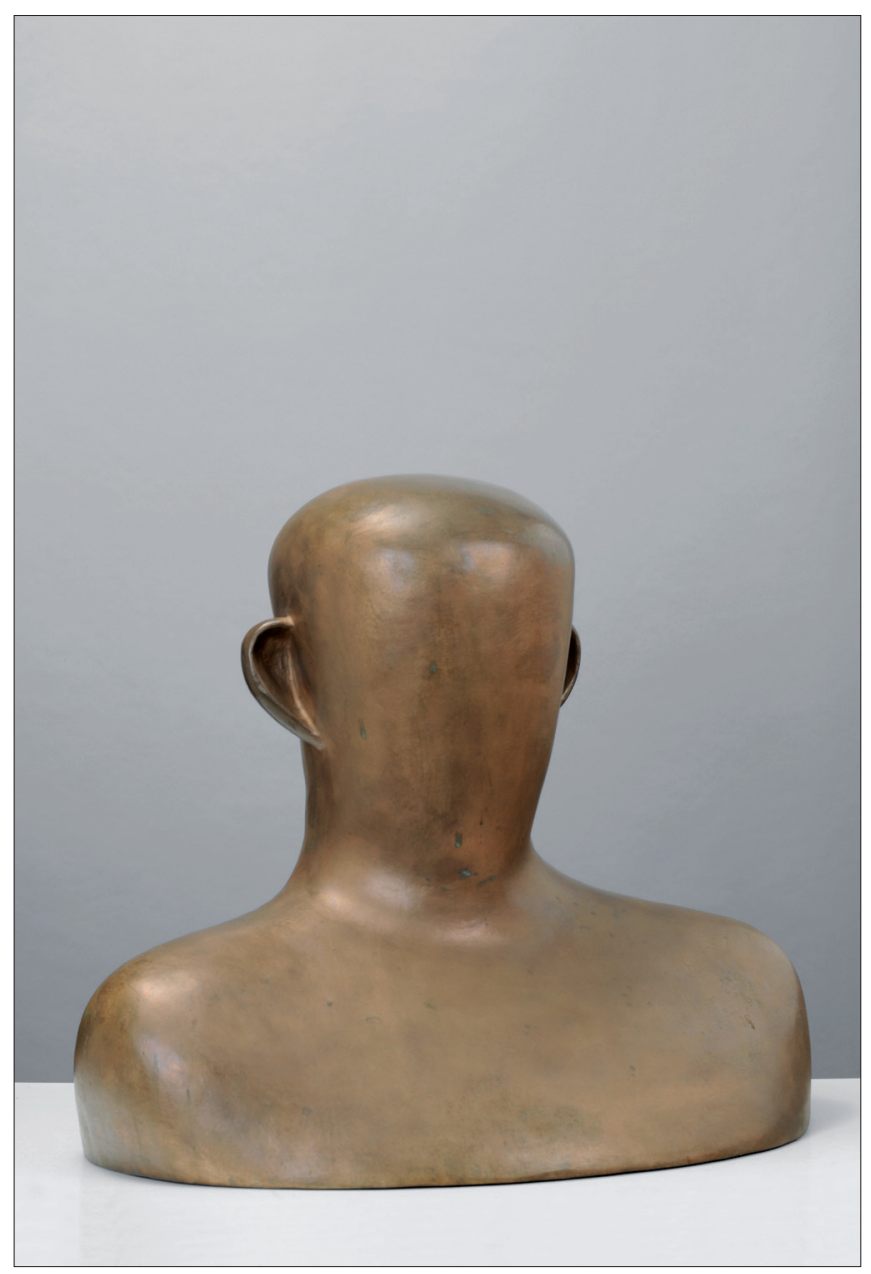

Obr. 6. Muž (1992), bronz, výška 52 cm. Foto: Jiří Horák a Michal Horák. Man (1992), bronze, height $52 \mathrm{~cm}$.

Mann (1992), Bronze, Höhe $52 \mathrm{~cm}$.

Heads of the Tvarožná neighbours become a main source of inspiration for Czech modern sculpture; the artist is able to penetrate their peculiar mentality through the abbreviation of succinct shape and colour. A lifelong motif, to which he always returns in his sculptural work, is the horse - his great love and pure hearted friend. He is also fascinated by the animal sensuality of the living organism - its warmth, softness, elasticity and, on the subject of pairs, the unity of the eternal contrasts of the basic links of the human race. He returns to the eternally disquieting Venus, the one who gives and maintains life - as if he were accepting a mysterious legacy from the hands of a pre-historical artist touched be the mystery of her legacy and creating the first image of woman. A significant part of Drápal's work is composed of bas-relief, which reached its artistic climax in the 1980s, especially in the bronze variations of Dvojice (Pairs). Their thinly layered compositions, with a sensitively modulated surface and luminously refined contour of sublime sensuality, harmony and refinement, allude to the spirit of the master works of Ancient Egyptian relief. The sculptural work of Vladimír Drápal is characterized by the robust, powerfully arched and expansive volumes of

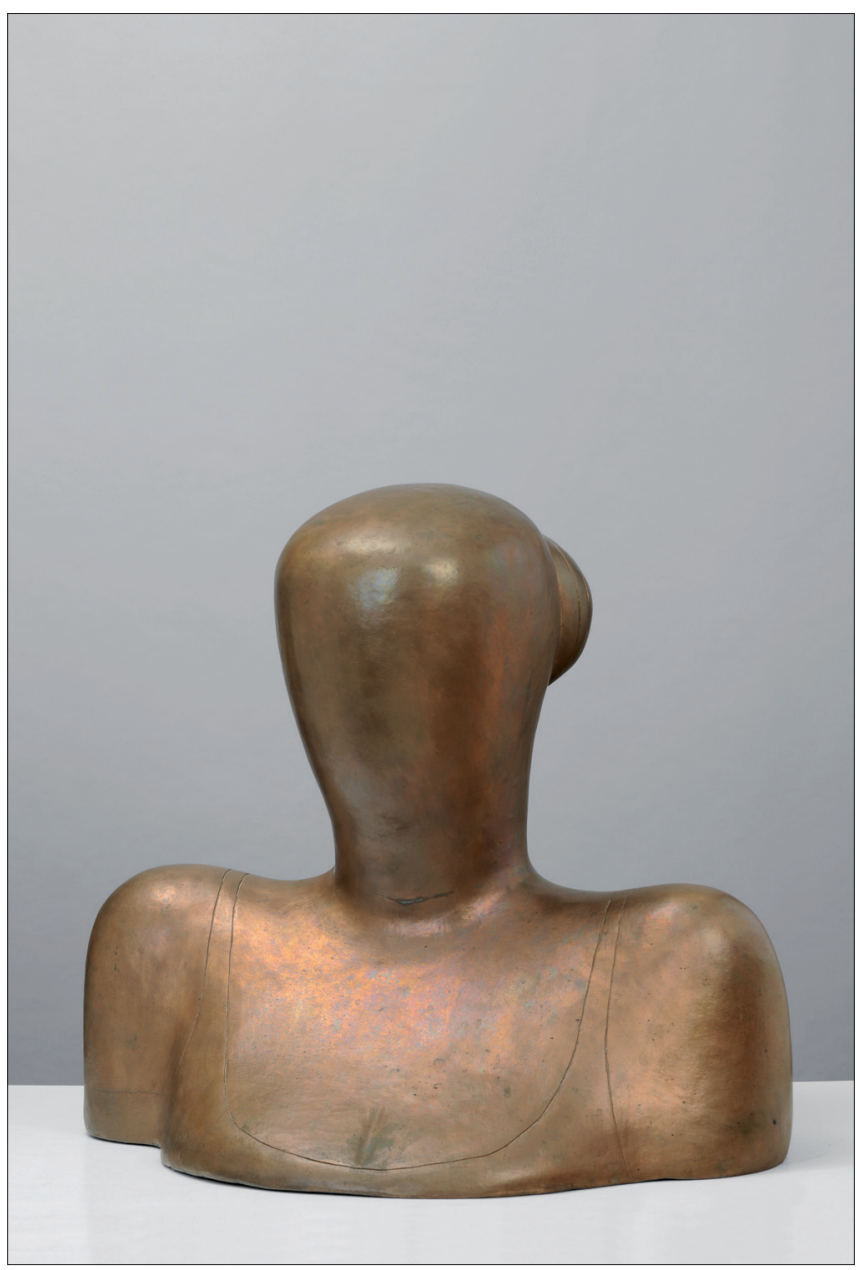

Obr. 7. Žena (1992), bronz, výška 52 cm. Foto: Jiří Horák a Michal Horák. Woman (1992), bronze, height $52 \mathrm{~cm}$.

Frau (1992), Bronze, Höhe $52 \mathrm{~cm}$.

massive internal tension, accentuated by functional cuts of graphic origin. With poignancy and frankness as well as the harsh immediacy of their expression, the sculptures are reminiscent of the early stages of artistic styles of the past.

The logical outcome of Drápal's oeuvre from the end of the 1960 s tends to be his sculptural work, which distinctively completes the nature of especially Brno and Moravian interiors and exteriors. Their penetration of thought, expanding shape in the urgency of a challenge, their sense of order and large form testify to the natural predispositions of the artist to monumental work.

Vladimír Drápal intermittently completes his large-scale sculptural work with small-scale ceramic, wax and glass works. Always attracted by the expressiveness of colour, the artist has returned to painting in various waves, drawing on subject matter from his native environment, with which he began his artistic career in the 1940s. His tempera heads are a product of his last wave, as are his illustrations on glass and his countless drawings of trees.

In its core, the oeuvre of Vladimír Drápal is compact and original. For years he has been patiently maturing through his 
own experience. He is optimistic, honest and humane. His work comprises a significant chapter of the Czech fine arts of the second half of the 20th century.

The life and work of Vladimír Drápal are described in more detail in the following monograph: Hlaváčková, Milada Hlušička, Jiří - Malina, Jaroslav, Vladimír Drápal. Brno: Akademické nakladatelství CERM, 2010.

(Translation by Šárka Roušavá)

\section{VLADIMÍR DRÁPAL}

Vladimír Drápal, Maler, Grafiker und Bildhauer, stammt aus Tvarožná, einem mährischen Dorf am südlichen Fuße des Drahaner Berglandes. Hier wurde er am 28. Oktober 1921 geboren. Er sollte Bauer und Bäcker werden, ebenso wie sein Vater. Von Kindheit an arbeitete er also in der Landwirtschaft und erlernte auch das Bäckerhandwerk. Über seine Laufbahn entschied er jedoch anders, indem er in die Kunstgewerbeschule in Brünn eintrat. In den Jahren 1938-1942 studierte er dort in der Spezialklasse für dekorative Malerei unter der Leitung von Professor Emanuel Hrbek. Seine weitere Ausbildung wurde aber durch den Krieg und die deutsche Besatzung des Landes unterbrochen. Während des Krieges wurde er als Zwangsarbeiter in verschiedenen Betrieben eingesetzt, seit Ende 1944 nahm er am Ausheben der Schützengräber im österreichischen Menhof teil. Nach der Befreiung der Tschechoslowakei studierte er in den Jahren 1945-1949 an der Hochschule für Angewandte Kunst, wo er das Spezialatelier für angewandte Malerei von Professor Josef Kaplický besuchte. Nach dem Studiumsabschluss kehrt er auf die Dauer in seinen Heimatort zurück, half seinem Vater beim Wirtschaften und beteiligte sich begeistert an Vereins- und Ausstellungsaktivitäten der Brünner Künstler. 1961 begann er mit der pädagogischen Tätigkeit an der Philosophischen und Pädagogischen Fakultät der Masaryk-Universität (damals umbenannt in JanEvangelista-Purkyně Universität) in Brünn.

Als Schlüssel zum Werk Vladimír Drápals ist eine tiefe Werwurzelung in seinem Heimatort zu betrachten. Durch das Prisma dieses harmonischen Gefühls, das ihn von Kindheit an formte und ihm den Weg zur Natur öffnete, nimmt er die Welt wahr. Die Natur, deren Leben spendende Kraft ihn fasziniert, hat es ihm für immer angetan. Die Naturordnung zu durchdringen, die Spreu vom Weizen zu trennen, lernte er jahrelang hinter dem Pflug. Alles, was seine Hände schufen, war geerdet wie Wiege, Erde, Brot, Mutter. Domäne des Künstlers Vladimír Drápal ist die Wirklichkeit. Er nähert sich ihr an, erfasst sie mit seinen Sinnen, Gefühlen und seinem Verstand, um ihre Oberfläche zu durchdringen. Auf diesem Wege sammelt er Erlebnisse auf und gelangt zu einer vollendeten Vorstellung des Wesentlichen, was er anschließend mit der absoluten Sicherheit der Metallprägung zum Ausdruck bringt.

Ein Schwerpunkt der breit gefächerten Kunstproduktion Vladimír Drápals liegt im Bereich der Zeichnung, die eine tragende Rolle in seinem Schaffen spielt. Eine vitale, spannungsreich und prägnant gestaltete Umrisslinie wölbt sich

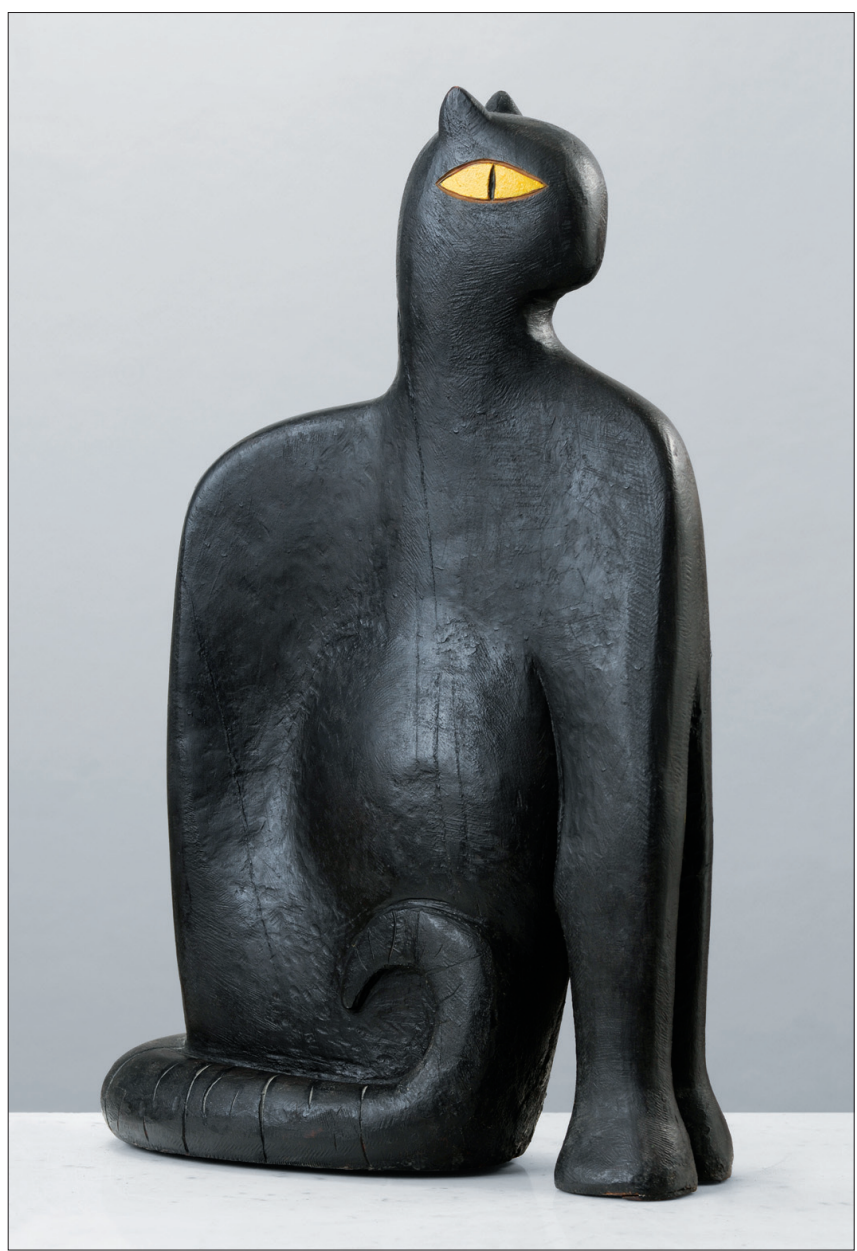

Obr. 8. Černá kočka (1996), mořené dřevo, výška $62 \mathrm{~cm}$. Foto: Jiří Horák a Michal Horák

Black Cat (1996), stained wood, height $62 \mathrm{~cm}$.

Schwarze Katze (1996), gebeiztes Holz, Höhe $62 \mathrm{~cm}$.

und gelangt $\mathrm{zu}$ einer dynamisch expansiven Form. In dem rauen Duktus seiner Zeichnungen scheint der monumentale Rhythmus des Naturpanoramas nachzuklingen. Auch wenn sich im gesamten Kunstwerk Drápals ein allmählicher Abstrahierungsprozess logisch und kontinuierlich entwickelt und durch eine Hyperbel und Änderung der Form auf das Linearzeichen hinzielt, werden die Aussagekraft, die robuste Sinnlichkeit und die Ausdrucksstärke seiner Zeichnungen keinesfalls geschwächt. Insbesondere die Zeichnung verrät den expressionistischen Ursprung der bildnerischen Aussage Vladimír Drápals.

Im Vordergrund seines Interesses standen sein gesamtes Leben lang der Mensch und das Tier - des Menschen ewiger Freund. In deren Lebensraum taucht der Künstler mit seinen ideenreichen zeichnerischen Zyklen ein, die in der Ätz- und Kaltnadeltechnik ausgeführt worden sind. So entstanden seine Zeichnungen Erdarbeiterinnen aus Tvarožná (1960), Bauernkopf (1964-1965), Pferd (1966-1968), Venus (1967), Ein Paar (1968-1969), Tier (1969-1973) und Genossenschaftlerinnen auf Fahrrädern (1975-1976). Seit Ende der sechziger Jahre dienten sie als Inspiration für seine Plastiken, die später 
in Keramik, Holz und Metall ausgeführt wurden. Das zunehmende Bestreben des Künstlers, die Realität in ihrer Materie und Variabilität zu erfassen, wurden hiermit befriedigt.

Ein besonderes und für die tschechische Bildhauerkunst anregendes Kapitel des plastischen Werks von Vladimír Drápal stellen keramische und hölzerne Köpfe seiner Nachbarn und Nachbarinnen aus Tvarožná dar, deren Mentalität er prägnant und aphoristisch in Form und Farbe zum Ausdruck bringt. Ein wiederkehrendes Thema in seinem Bildhauerwerk ist das Pferd - seine große Liebe, sein Freund mit dem reinen Herzen. Bei Pferden bewundert er ihre anregende tierische Sinnlichkeit, ihre Wärme, Weichheit des Leders und Spannkraft. Beim Motiv der Paare legt er besonderen Wert auf die Einheit der Gegensätze, der ewigen Widersprüchlichkeit zwischen beiden Geschlechtern. Wiederholt tritt bei ihm das beunruhigende Motiv der Venus hervor als mystische Botschaft eines urzeitlichen Künstlers, der, beeindruckt von der Berufung der Frau zur Mutterschaft, die erste Frauenfigur knetete. Einen bedeutenden Teil des künstlerischen Schaffens von Vladimír Drápal stellt das niedrige Flachrelief dar. Diese Art Skulptur erreicht in den achtziger Jahren ihre Vollendung in Drápals bronzenen Variationen von Paaren. Flache Schichten dieser Kompositionen mit einer feinfühlig modulierten Oberfläche und einem Umriss, der so raffiniert gestaltet ist, dass er bei Lichtwechsel unterschiedlich wirkt, erinnern durch ihre sublimierte Sinnlichkeit, Harmonie und Noblesse an meisterhafte altägyptische Reliefs.

Ein kraftvoll gewölbtes expansives Volumen von starker Innenspannung, akzentuiert durch funktionelle Ritze graphischer Herkunft, ist für das plastische Schaffen Vladimír Drápals kennzeichnend. Seine Plastiken überzeugen durch ihre aufrichtige Aussage, raue Unmittelbarkeit und klare Formsprache, so dass sie an frühe Perioden der Kunstgeschichte erinnern.

Bereits seit Ende der sechziger Jahre findet das Schaffen Vladimír Drápals seinen Ausdruck in Skulpturen, die den Charakter von zahlreichen Innen- und Außenräumen in Mähren und Brünn deutlich abrunden. Die Ideenkraft des Künstlers, dessen Werke den Betrachter herausfordern, sein Sinn für Ordnung und Gespür für Großformat bezeugen seine natürliche Begabung für monumentale Kunst.

Vladimír Drápal ergänzt seine Plastiken stets mit Kleinke- ramik, Wachs- und Glasplastik. Auf Heimatmotive, mit denen in den vierziger Jahren seine künstlerische Bahn begann, greift der von Expressivität der Farben beeindruckte Künstler in einigen Wellen zurück. Aus der letzten Zeit stammen seine in Tempera gestalteten Köpfe, Bilder auf Glas und unzählige Zeichnungen von Bäumen.

Das Werk von Vladimír Drápal ist in seinen Wurzeln kompakt und eigenständig. Seit Jahren reift es durch Selbsterkenntnis. Sein optimistisches, wahres und menschenfreundliches Schaffen bildet ein beachtenswertes Kapitel der tschechischen bildenden Kunst der zweiten Hälfte des zwanzigsten Jahrhunderts.

Eine ausführliche Beschreibung des Lebens und der Werke Vladimír Drápals bringt die Monographie: Hlaváčková, Milada - Hlušička, Jiří - Malina, Jaroslav, Vladimír Drápal. Brno: Akademické nakladatelství CERM, 2010.

(Übersetzung von Alena Opletalová)

\section{LITERATURA}

Hlaváčková, Milada - Hlušička, Jiř́i - Malina, Jaroslav (2010): Vladimír Drápal. Brno: Akademické nakladatelství CERM.

Malina, Jaroslav (2010): Projekt Kruh prstenu aneb antropologie sexuality: Zdeněk Macháček. Anthropologia integra, 1, 1, 71-90.

Malina, Jaroslav a kolektiv (2007): Kruh prstenu: Světové dějiny sexuality, erotiky a lásky od počátkư do současnosti v reálném životě, krásné literatuře, výtvarném umění a dílech českých malírù a sochařo inspirovaných obsahem této knihy, 1. „Celýsvět" kromě euroamerické civilizace. Brno: Akademické nakladatelství CERM.

Malina, Jaroslav a kolektiv (2009): Antropologický slovník aneb co by mohl o člověku vědět každý člověk (s přihlédnutím k dějinám literatury a umění). Brno: Akademické nakladatelství CERM.

\section{AUTOR}

Malina, Jaroslav (11. 4. 1945, Dolní Bučice u Čáslavi), český sociokulturní antropolog, archeolog a spisovatel; profesor antropologie na Ústavu antropologie Př́rodovědecké fakulty Masarykovy univerzity; viz: http://anthrop.sci.muni.cz/page.yhtml?id=468.

Kontakt: Prof. PhDr. Jaroslav Malina, DrSc., Ústav antropologie Př́rodovědecké fakulty Masarykovy univerzity, Vinařská 5, 60300 Brno, e-mail: jmalina@sci.muni.cz. 